\title{
Permasalahan Pola Asuh dalam Mendidik Anak di Era Digital
}

\author{
Ahmad Muslih Atmojo ${ }^{\circledR}$, Rahma Lailatus Sakina ${ }^{2}$, Wantini ${ }^{1}$ \\ Pendidikan Agama Islam, Universitas Ahmad Dahlan, Indonesia(1) \\ Pendidikan Psikologi, Universitas Negeri Malang, Indonesia( ${ }^{(2)}$ \\ DOI: 10.31004/obsesi.v6i3.1721
}

\begin{abstract}
Abstrak
Orang tua saat ini dihadapkan dengan berbagai problematika yang terjadi dalam mendidik anak di tengah perkembangan digital yang begitu pesat. Sontak, hal ini menimbulkan berbagai kekhawatiran terhadap tumbuh kembang anak. Artikel ini bertujuan untuk mengupas problematika yang terjadi dalam proses mendidik anak di era digital seperti sekarang ini. Seluruh persoalan mendidik anak seharusnya diatasi dengan pola dan pendekatan yang tepat. Penelitian ini menggunakan pendekatan research synteshis dalam menggali teori yang relevan terkait issue yang dibahas. Analisis secara kualitatif menjadi tombak penelitian untuk memantapkan akurasi data yang dikumpulkan. Di era ini, banyak anak-anak yang memiliki perilaku ketergantungan terhadap perangkat digital yang cukup riskan terhadap sisi negatif. Oleh karena itu, pentingnya mengendalikan digital era yang dipegang oleh anak-anak untuk memfokuskan bidang pendidikan perlu dilakukan supaya motivasi dapat terbentuk dan tujuan pendidikan juga bisa tercapai dengan baik dengan sinergisitas antara stakeholder lembaga pendidikan (sekolah) dengan yang lainnya (tri logi pendidikan).
\end{abstract}

Kata Kunci: permasalahan pola asuh; mendidik anak; era digital

\begin{abstract}
Parents are currently faced with various problems that occur in educating children amid such rapid digital development. Suddenly, this raises various concerns about the growth and development of children. This article aims to explore the problems that occur in the process of educating children in the digital era like today. All problems educating children should be addressed with the right pattern and approach. This study uses a research synteshis in exploring relevant theories related to the issues discussed. Qualitative analysis is the spearhead of research to strengthen the accuracy of the data collected. In this era, many children are dependent on digital devices which are quite risky to the negative side. Therefore, the importance of controlling the digital era held by children to focus on the field of education needs to be done so that motivation can be formed and educational goals can also be achieved properly with synergy between stakeholders of educational institutions (schools) and others (educational trilogy).
\end{abstract}

Keywords: The Parenting Problems; Educating Children; Digital Era

Copyright (c) 2021 Ahmad Muslih Atmojo, et al.

$\square$ Corresponding author:

Email Address : atmojo2007052022@webmail.uad.ac.id (Bantul, Yogyakarta, Indonesia)

Received 23 May 2021, Accepted 30 October 2021, Published 24 November 2021 


\section{PENDAHULUAN}

Pokok permasalahan dalam mendidik anak saat ini adalah sulitnya menggugah motivasi peserta didik untuk sadar akan pentingnya belajar. Salah satu hal yang menyebabkan merosotnya motivasi belajar anak adalah penggunaan smartphone yang tidak semestinya. Para siswa terlalu sering menggunakan smartphone untuk mengakses sesuatu yang sebetulnya kurang bermanfaat seperti permainan game, hiburan, dan media sosial (Sobon et al., 2020). Padahal, motivasi merupakan roda penggerak utama dalam diri seseorang untuk melakukan sesuatu termasuk dalam persoalan belajar (Yuliawan, 2016). Hal ini yang seakan menjadi sekat penghalang pendidik dan juga anak untuk bisa maju dalam belajar. Di era digital seperti sekarang ini, smartphone menjadi suatu konsumsi yang bisa dinikmati oleh mayoritas orang dengan mudah termasuk anak-anak. Dalam hal ini, orang tua dituntut supaya lebih aktif dalam mengawasi anak agar penggunaan smartphone tidak berlebihan. Intensitas dalam sebuah keluarga menjadi sebuah hal yang penting karena ukuran keharmonisan hubungan keluarga dapat dilihat dari hal ini termasuk antara orang tua dengan anak (Rofiq \& Nihayah, 2018).

Sebetulnya ada banyak permasalahan dalam mendidik anak di era digital seperti ini, namun persoalan yang paling mencolok adalah yang berkaitan dengan motivasi siswa karena terhalang oleh godaan smartphone. Permasalahan-permasalah seperti ini harus diatasi dengan pola dan pendekatan yang tepat. Yang masih menjadi pertanyaan besar adalah sejauh mana teknologi di era digital seperti ini bisa efektif menjadi penyebab berubahnya sistem pendidikan secara mendasar (Ikawati, 2021). Dalam tri logi pendidikan, tanggungjawab mendidik anak tidak hanya dibebankan pada sekolah saja, namun keluarga dan lingkungan juga. Jadi, permasalahan seperti ini bisa dituntaskan dengan kerjasama antara tiga atmosphere ini. Banyak orang tua yang berpendapat bahwa pendidikan utama anak hanyalah di lingkungan sekolah sehingga mereka mempercayakan seutuhnya pola pendidikan tersebut (Trianingsih, 2016). Padahal, ini justru akan mengacaukan kesinambungan tri logi pendidikan tadi karena orang tua merasa lepas tangan terhadap pendidikan anak mereka. Dalam persoalan ini, motivasi menjadi bagian terpenting dalam kegiatan pendidikan. Motivasi yang berasal dari orang tua dan yang bersumber dari diri sendiri akan mampu menggerakkan proses pendidikan agar berjalan dengan baik (Yuhana \& Aminy, 2019).

Mendidik anak di tengah tantangan zaman seperti sekarang menjadi satu hal yang sulit untuk dilakukan secara maksimal karena berbagai pengaruh yang datang seiring perkembangan zaman. Di mana, pada era ini banyak anak-anak yang memiliki perilaku ketergantungan terhadap perangkat digital yang cukup riskan terhadap sisi negatif (Rahmat, 2018). Hal ini berimbas langsung pada karakteristik anak yang begitu tampak di laman media sosial seperti facebook, twitter, instagram, dll. Dalam dunia pendidikan, pola pendidikan etika amat penting peranannya untuk membentengi anak-anak dari sisi negatif pemanfaatan media digital yang bisa diterapkan pada lingkungan pendidikan itu sendiri, keluarga, maupun masyarakat (Bakti \& Meidasari, 2014). Meskipun begitu, orang tua tetap memiliki peran penting dalam proses pendidikan mereka karena orang tua adalah guru yang paling utama bagi anak-anak (Dunham et al., 2012). Bagaimanapun, orang tua lah yang mengajarkan banyak hal kepada anak dari setiap tahapan terutama pada masa golden age (Trisnawati \& Sugito, 2020). Ini lah yang seharusnya menjadi PR penting bagi para orang tua khususnya terkait dengan banyaknya permasalahan yang muncul di tengah tumbuh kembangnya anakanak mereka terutama yang disebabkan oleh perangkat digital saat ini.

Aslan dalam penelitiannya yang berjudul "Peran pola asuh orangtua di era digital" menerangkan bahwa model atau cara asuh orang tua saat ini hendaknya mengikuti perkembangan zaman yang ada. Teknologi digital yang begitu canggih mampu memberikan sinkronisasi terhadap perubahan pola asuh yang dilakukan sehingga mampu mengatur beberapa pola seperti otoriter, demokratis, dan permisif supaya lebih terkendali (Aslan, 2019). Kemudian, Isnanita dalam artikelnya menambahkan bahwa pendidikan anak dalam keluarga di era digital membutuhkan upaya yang lebih ekstra jika dibandingkan dengan zaman-zaman 
sebelumnya. Ia menambahkan beberapa tahapan yang harus dilakukan oleh orang tua dan anak dalam mempertahankan pola asuh yang baik di era digital seperti ini, antara lain: (a) tanggung jawab secara penuh, (b) kedekatan emosional, (c) tujuan pendidikan yang jelas, (d) menjaga komunikasi dengan baik, (e) mengajarkan agama, (f) persiapkan anak masuk masa pubertas, (g) persiapkan anak masuk era digital (Andriyani, 2018). Di sisi yang lain, Stephanus Turibius Rahmat berpendapat bahwa setiap generasi memiliki karakteristik yang berbedabeda karena hal tersebut ditentukan dengan kondisi demografis yang ada. Maka, peran orang tua untuk menghalau berbagai permasalahan negatif yang muncul di era anak-anak itu tumbuh tentu saja sangat diperlukan termasuk di era digital saat ini (Rahmat, 2018).

Penelitian-penelitian yang berhubungan dengan pola asuh dan pendidikan anak dalam keluarga di era digital ini lebih banyak membahas mengenai pola umum yang sebetulnya belum ditemukan sama sekali cara yang paling ampuh untuk mengatasi berbagai permasalahan yang muncul di era ini. Bahkan, Hasnawati dalam penelitiannya mengungkapkan bahwa masih belum ada penyelsaian mengenai permasalahan bagi orang tua dalam mendidik anak di era digital. Hal ini membuat penulis merasa bahwa persoalan ini perlu dikaji lebih jauh agar nantinya orang tua selaku pendidik utama dalam keluarga memahami segala roles dan pengetahuan yang ada untuk meminimalisir dampak negatif dari era digital terhadap anak-anak.

\section{METODOLOGI}

Penelitian ini masuk ke dalam jenis penelitian Systematic Review. Penelitian ini (Systematic Review) juga dikenal dengan istilah Research Synthesis yang bertujuan untuk memberikan sintesis yang tepat dan komprehensif dari berbagai studi yang relevan di dalam dokumen tunggal (Aromataris \& Pearson, 2014).

Pendekatan pengembangan penelitian yang digunakan adalah meta-analysis. Artinya bahwa penelitian ini berfokus pada berbagai macam karakteristik dan quantitative findings, menganalisa, dan mendeskripsikan hasil temuan secara kolektif dengan data yang valid dan cara yang benar (Lipsey \& Wilson, 2001). Kemudian peneliti juga melakukan kajian secara ilmiah terkait dengan literatur-literatur perpustakaan yang relevan dengan judul penelitian, kemudian dijabarkan dan dianalisis secara kualitatif. Penelitian kualitatif adalah salah satu metode penelitian yang bertujuan untuk mendapatkan pemahaman tentang kenyataan melalui proses berfikir induktif (Khilmiyah, 2016:3).

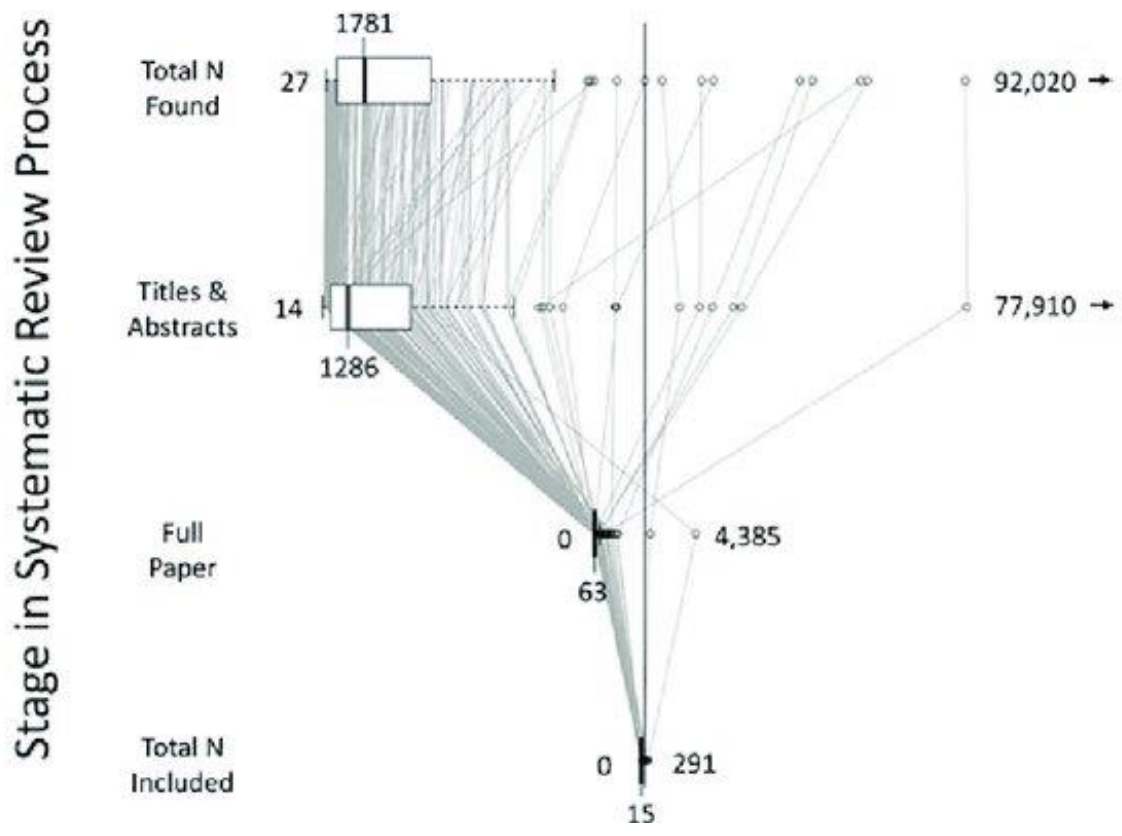

Gambar 1. Tahapan Proses Systematic Review 
Penelitian ini adalah penelitian sintesis yang dimaksudkan untuk mengumpulkan informasi mengenai variabel atau tema, indikasi atau keadaan yang ada yaitu keadaan sebagaimana adanya ketika penelitian dilakukan. Penelitian ini dilakukan pada tahap eksplorasi secara umum dan memperhatikan aspek pada elemen kondisi sosial yang diamati, sehingga dapat diperoleh gambaran secara umum (Khilmiyah, 2016: 234).

Secara umum, hampir seluruh tipe dari systematic review menginformasikan sitematika proses secara general. Proses-proses seperti ini dapat terbagi lagi di dalamnya secara jelas namun tetap saling berhubungan antar tahapan-tahapannya seperti bagan di bawah ini. Systematic review memerlukan penyederhanaan pertanyaan penelitian dan metode-metodenya yang akan digunakan untuk menginvestigasi pertanyaan-pertanyaan tersebut (Kerres \& Bedenlier, 2020). Desain penelitian diilustrasikan dengan gambar 1.

\section{HASIL DAN PEMBAHASAN \\ Pendidikan Anak Era Digital}

Pendidikan anak saat ini semakin terbantu oleh adanya teknologi secara masif. Anakanak sekarang tumbuh bersamaan dengan tumbuhnya teknologi pula yang semakin pesat seperti smartphone, laptop, dan berbagai aplikasi lainnya (Andriyani, 2018). Warna-warni pendidikan model ini bersebaran dimana-mana termasuk di dalam keluarga itu sendiri di mana orang tua memiliki pengaruh penting terhadap pertumbuhan anak terutama dalam masalah perilaku yang diinterpretasikan dari atmosphere keagamaan dalam keluarga(El Fiah \& Hizri, 2020) .Oleh karena itu dalam situasi seperti ini pun keluarga memiliki peran penting dalam mendampingi proses pendidikan anak. Permasalahan dalam keluarga sendiri sekarang lebih kompleks, salah satu penyebabnya adalah teknologi. Fungsi komunal antara orang tua dan anak terhalang oleh teknologi, terbukti dengan kesibukan mereka terhadap gadget yang dipegang (Alia \& Irwansyah, 2018).

Faktanya bahwa perkembangan teknologi digital membuat anak menjadi lebih fokus hanya kepada digital itu sendiri seperti contoh bermain game, kurangnya kepekaan terhadap lingkungan sekitar, kurangnya hubungan sosial, bahkan malas untuk belajar (Baharun \& Finori, 2019). Ini lah gambaran umum dunia anak zaman sekarang terutama jika dikaitkan dengan pendidikan. Lazimnya, anak-anak itu lebih fokus terhadap belajar untuk mempersiapkan masa depan yang lebih baik. Seharusnya anak berada pada fase berfikir secara berangsur-angsur, kemudian memperkuat hafalan sehingga menimbulkan kegembiraan dalam belajar untuk menambah pengetahuan dan kemampuannya (Khusni, 2018).

Maka, pentingnya mengendalikan anak zaman sekarang agar mampu memanfaatkan teknologi seperti sebagaimana mestinya dan supaya tidak salah dalam penggunaannya. Meskipun tujuan diciptakannya teknologi adalah supaya membawa dampak positif bagi para penggunanya, namun banyak juga para pelajar khususnya yang menggunakan fasilitas teknologi tidak sesuai dengan yang semestinya sehingga dampak negatif yang lebih dominan timbul (Marryono Jamun, 2018). Oleh karena itu pentingnya pengawasan terhadap anak yang hidup di era ini perlu ditingkatkan dan dimotivasi agar fungsi teknologi bisa digunakan untuk mengkonstruksi pengetahuan dan menunjang pembelajaran (Andri, 2017).

\section{Pola Asuh Orang Tua di Era Digital}

Pola asuh orang tua merupakan ujung tombak dari sikap atau perilaku yang dimiliki oleh anak. Hal ini menjadi penting karena pola komunikasi, interaksi, dan lainnya dipengaruhi oleh pola asuh tersebut (Amalia Safitri et al., 2020). Pola adalah model, kemudian istilah asuh itu sendiri merujuk pada makna bahasa menjaga, mendidik, atau merawat anak agar tumbuh kemampuan mandiri dari anak untuk berdiri di atas kakinya sendiri (Anisah, 2017). Dewasa ini, pola asuh orang tua lebih mengarah pada teknologi digital, pasalnya orang tua sekarang memanfaatkan smartphone untuk mengasuh anak-anaknya supaya tidak 
menangis dan sebagainya. Teknologi memiliki manfaat besar dalam pertumbuhan dan pendidikan anak. Berbagai literasi dapat dengan mudah didapatkan oleh siapapun untuk menunjang pengetahuan seperti melalui laman Google, dan lainnya (Putri, 2018).

Pola asuh yang serba tergantung dengan model digital ini memiliki dampak yang cukup serius bagi pertumbuhan anak, baik itu dampak positif ataupun dampak negatif. Salah satu dampak nyata yang saat ini diresahkan oleh berbagai kalangan adalah merosotnya mora generasi bangsa yang disebabkan oleh teknologi informasi yang tidak diimbangi oleh nilai budi pekerti yang luhur di dunia nyata (Hendayani, 2019). Hal ini lah yang secara nyata ditanamkan oleh orang tua melalui pola asuh di era digital seperti ini. Kemudahan mengakses berbagai hal yang tidak bisa dipertanggung jawabkan implikasi jangka panjangnya bagi anak. Salah satunya adalah hilangnya nilai social dari dalam diri anak-anak. Hal ini seharusnya diimbangi dengan contoh atau pengajaran nyata oleh orang tua tentang budi pekerti yang luhur dan sikap sosial yang baik antar sesama (Nahriyah, 2017). Orang tua bertugas untuk mendampingi dan mengarahkan anak-anak dalam pemanfaatan teknologi di era digital supaya dampak negatif dari pemanfaatan ini bisa terbentengi. Ini lah salah satu bentuk ataupola asuh yang bisa diterapkan oleh orang tua terhadap anak-anak di era digital seperti ini.

\section{Pembahasan}

Pada kondisi yang serba digital seperti ini, orang tua dihadapkan dengan tantangan pola asuh dalam proses pendidikan anak yang lebih kompleks. Ada banyak permasalahan yang muncul seiring pertumbuhan dan perkembangan zaman. Umumnya setiap 15-18 tahun periodisasi akan membentuk karakteristik demografi yang berbeda antara generasi sebelumnya dan juga setelahnya (Rahmat, 2018). Hal terjadi pula pada era digital yang semakin meluas seperti sekarang. Setidaknya dalam proses pendidikan ada yang namanya tri logi pendidikan yang memang tidak bisa dipisahkan. Maka, pola asuh yang berada dalam 3 lingkup pendidikan mengalami perubahan seiring berkembangnya ekonomi, teknologi, dan gender (Aslan, 2019). Hal ini memacu penulis untuk membahas berbagai permasalahan yang timbul di era digital ini.

\section{Permasalahan Umum}

Tidak bisa dipungkiri bahwa teknologi menuntut peserta didik menjadi manusia yang memiliki sumber daya unggul (SDM) khususnya di era digital seperti ini. Hal ini terbukti dengan tantangan dalam dunia pendidikan termasuk di dalamnya proses mendidik anak di era digital seperti sekarang terhadap penanaman nilai pendidikan itu sendiri yang sejatinya masih perlu dikembangkan (Syamsuar \& Reflianto, 2019). Pendidikan nilai ditujukan untuk membentuk karakter atau nilai yang ada dalam diri peserta didik sehingga diharapkan bisa menjadi manusia yang mampu menjaga harkat dan martabatnya dengan baik.

Namun pada kenyataanya, pesatnya arus teknologi di era digital justru membuat anak-anak terbawa oleh arus sehingga memicu sikap tidak mau bertanggung jawab, degradasi moral, serta meningkatnya kasus kejahatan di kalangan pelajar (Syamsuar \& Reflianto, 2019). Hal ini terjadi karena mudahnya mereka mengakses informasi dan komunikasi dengan menggunakan terknologi melalui laman media sosial secara online. Ini lah permasalahan umum yang terjadi, sehingga siswa lebih menitik beratkan pada lingkaran teknologi ini dari pada belajar. Problematika yang kompleks seperti ini tentu saja berpengaruh terhadap proses pendidikan siswa, juga kepada guru dalam menyiapkan strategi sebagai fasilitator yang seharusnya dapat mengurangi problem yang terjadi di lingkaran peserta didik itu sendiri (Hardiyanto, 2020).

Beberapa permasalahan umum yang terjadi digambarkan dalam penelitian Mira Rahmawati tentang penggunaan gawai (Rahmawati \& Latifah, 2020), sebagaimana dapat dilihat pada tabel 1. 
Tabel 1. Prosentase permasalahan umum dalam mendidik anak di era digital.

\begin{tabular}{clc}
\hline \multirow{2}{*}{ No. } & \multicolumn{1}{c}{ Permasalahan Umum } \\
\hline 1. & Ketergntungan terhadap gadget & Prosentase \\
2. & Kurangnya pengawasan digital oleh orang tua & $4,9 \%$ \\
3. & Perhadap anak & $51,6 \%$ \\
\hline
\end{tabular}

\section{Permasalahan Khusus di Sekolah}

Permasalahan khusus yang sering terjadi di sekolah adalah kurangnya motivasi peserta didik. Motivasi yang diharapkan bisa tumbuh subur di sekolah justru melemah karena adanya gangguan dari perangkat digital seperti smartphone. Pada era digital seperti ini, dunia pendidikan dihadapkan dengan perubahan yang cukup signifikan. Seharusnya hal ini justru dapat dimanfaatkan lembaga pendidikan sebagai cara untuk meningkatkan mutu pendidikan yang ada termasuk pemanfaatan perangkat pembelajaran seperti smartphone (Barni, 2019).

Namun, kontrol terhadap penggunaan perangkat digital di sekolah juga tidak bisa terlaksana dengan baik karena banyaknya jumlah siswa yang ada. Terlebih lagi, banyak tenaga pendidik di Indonesia yang masih belum bisa melek akan teknologi sehingga mempersulit mereka dalam mengawasi peserta didik. Hal ini dibuktikan dengan survey yang menunjukkan bahwa sebanyak 62, 15\% guru jarang memanfaatkan teknologi khususnya dalam pembelajaran (Syamsuar \& Reflianto, 2019). Tentu hal ini menjadi penting karena dalam mengontrol siswa yang saat ini sudah bisa menggunakan teknologi, para pendidik pun seharusnya juga bisa mengimbanginya dengan cara bisa memanfaatkan teknologi itu sendiri.

\section{Permasalahan Khusus di Rumah}

Permasalahan mendidik anak tampaknya juga terjadi di dalam rumah, lebih-lebih di era digital yang ternyata justru memecah fungsi komunal dalam sebuah keluarga. Kebanyakan orang tua sekarang memberikan fasilitaf berupa smartphone kepada anaknya agar sang anak menjadi tenang atau tidak rewel di kala orang tua sedang sibuk (Baharun \& Finori, 2019). Tanpa mereka sadari bahwa tanggung jawab anak terhadap digita itu masih perlu diawasi. Seharusnya orang tua membatasi anak dalam hal penggunaan perangkat digital dan berusaha mengalihkannya kepada belajar atau membangun tanggung jawab belajar secara mandiri di rumah.

Pada dasarnya, anak juga belum bisa selektif dalam memilih media yang tepat untuk usia mereka. Maka, di sini lah pentinya peran orang tua untuk menjadi pengawas bagi anakanak sehingga dampak negative dari era di gital khususnya yang terjadi di lingkungan keluarga bisa dihindari. Namun, kebanyakan orang tua sekarang justru sibuk bekerja dan terkesan kurang peduli terhadap proses pendidikan anak dalam keluarga, hal ini tentu saja memeiliki dampak yang cukup serius terhadap proses belajar anak karena didikan orang tua merupakan tonggak utama dari keberhasilan anak dalam pendidikan (Yuhana \& Aminy, 2019).

\section{Permasalahan Khusus di Lingkungan Sosial}

Lingkungan sebagai salah satu tempat pendidikan bagi anak juga memiliki peran penting dalam membantu mendorong motivasi siswa terhadap pendidikan itu sendiri. Hal ini dibuktikan dengan makna pendidikan itu sendiri yang berarti usaha membantu peserta didik untuk mengembangkan potensi mereka terutama dalam menghadapi tantangan zaman seperti sekarang ini (era digital) (Ramdhani, 2014).

Problematika yang sering terjadi di lingkungan sekitar adalah bahwa peserta didik terlalu sibuk dengan gadget yang dimiliki sehingga melupakan hubungan sosial dengan orang lain. Di mana seharusnya lingkungan berfungsi untuk mendidik anak supaya bisa hidup sosial dan bermasyarakat secara aktif dengan dan tanpa adanya teknologi karena 
lingkungan terdiri dari material dan stimulus yang bersifat fisiologis, psikologis, dan sosialkultural (Nurulloh, 2019). Ini yang menjadi PR bagi lingkungan sekitar untuk menciptakan dan mengembalikan fungsi komunal anak-anak terhadap lingkungan sekitar termasuk bersosial dengan rekan-rekan sebayanya sehingga tumbuh motivasi terhadap belajar. Sikap seperti ini tidak serta merta bisa muncul tanpa ada dorongan dari diri dan lingkungan sosial mereka khususnya dalam proses pembentukan motivasi belajar siswa (Tamara, 2016). Salah satu cara yang bisa dilakukan adalah dengan memanfaatkan teknologi di era digital ini untuk mencapai tujuan itu, seperti membuatkan group atau kelompok belajar terbimbing bagi anakanak yang sebaya. Ini merupakan bentuk stimulus dari lingkungan sosial terhadap pendidikan anak di era teknologi digital seperti sekarang ini.

\section{Permasalahan Psikologi di Era Digital}

Terdapat tahapan masa perkembangan manusia mulai dari masa anak-anak sampai lansia. Pada masa anak-anak dan remaja lah pembentukan karakter dan kepribadian anak sangatlah pesat. Diketahui anak dengan usia 1-5 tahun banyak dikenal sebagai the golden age. Muhibbin (2012) mengungkapkan jika pada masa ini kecerdasan intelektual, emosi, dan spiritual mengalami perkembangan yang pesat. Dengan pesatnya perkembangan tersebut membuat anak ada pada masa golden age menjadi cepat menyerap informasi dan pintar meniru. Hal inilah yang akan mempengaruhi dan menentukan perkembangan selanjutnya.

Setelah masa anak-anak dilanjutkan dengan masa remaja. World Health Organization (WHO) mengungkapkan remaja berada pada usia antara 10 sampai 19 tahun. Masa remaja adalah masa transisi dari anak-anak menuju dewasa. Perkembangan pada masa ini tidak hanya ditandai dengan pesatnya perubahan pada fisik tetapi juga perubahan psikososial dan emosional sehingga peningkatan kapasitas kognitif dan intelektual. Richard J, Bonnie \& Emily. (2019) menyatakan adolescence (remaja) merupakan masa perkembangan yang signifikan dimana terjadi perubahan yang berkaitan dengan perkembangan biologis, kognitif, psikososial, dan emosional. Oleh sebab itu masa remaja dikenal sebagai masa rentan dan sensitif karena usaha untuk menyesuaian diri terhadap perubahan signifikan yang nantinya akan berdampak pada sikap dan perilaku.

Melihat pesatnya perkembangan pada masa remaja, maka peran orangtua dan orangorang disekelilingnya sangatlah besar. Karena itu menjadi salah satu tahap yang akan membentuk kepribadian dan karakter anak dimasa yang akan datang. Oleh sebab itu tahap perkembangan remaja harus didukung oleh pemahaman orang tua terhadap kondisi remaja yang sedang mencari jati dirinya (Umami, 2019). Besarnya peran orang tua sebagai kawan dan sahabat lebih diperlukan pada masa ini. Karena remaja sedang mengalami proses perkembangan biologis, kognitif, dan psikososial dan pengaruh proses ini bergantung pada karakteristik individu dan lingkungan tempat mereka tinggal, belajar, dan bermain.

Dewasa kini banyak remaja yang kecanduan gadget. Berdasarkan Survei Asosiasi Penyelenggara Jasa Internet Indonesia (APJII) tahun 2017, sebanyak 143,26 juta orang atau 54,68 persen dari populasi Indonesia menggunakan internet penetrasi, dimana pengguna internet terbesar di usia 13-18 tahun (Soemartono, 2018). Bahkan diperiode tahun 2019 sampai 2020 APJII mengumumkan jika penguna internet di Indonesia meloncat tajam menjadi 73,7 persen dari populasi, yang berarti hampir tembus 200 juta pengguna internet (APJII, 2020). Hal tersebut memperlihatkan bahwa pengguna internet di Indonesia terus mengalami lonjakan disetiap tahunnya.

Diketahui jika gadget memiliki dampak positif dan negatif bagi anak. Dampak positif diantaranya dapat membantu anak dalam melatih keterampilan kognitif yaitu menyerap informasi, mengingat dan menghubungkan objek. Selain itu juga dapat melatih motorik anak seperti gerakan jari tangan dan pergelangan tangan. Hal tersebut dikarenakan banyak sekali aplikasi interaktif dan fitur yang mendukung gerak motoric dari jari dan perhelangan tangan bagi anak. 
Tabel 2. Dampak negatif terhadap penggunaan gadget

\begin{tabular}{|c|c|c|c|c|}
\hline No. & $\begin{array}{c}\text { Dampak } \\
\text { Negatif }\end{array}$ & Penjelasan & Peran Gadget & Sumber \\
\hline 1 & $\begin{array}{l}\text { Keterlambatan } \\
\text { bicara }\end{array}$ & $\begin{array}{l}\text { Gangguan dalam } \\
\text { menggabungkan dua kata } \\
\text { atau lebih ketika anak } \\
\text { berbicara sehingga sulit } \\
\text { untuk dipahami. tetapi } \\
\text { orang lain sulit memahami } \\
\text { maksudnya. }\end{array}$ & $\begin{array}{l}\text { membuat anak } \\
\text { kehilangan waktu untuk } \\
\text { berinteraksi dan } \\
\text { berkomunikasi dengan } \\
\text { orang lain. }\end{array}$ & (Sundus, 2017) \\
\hline 2 & Kecemasan & $\begin{array}{l}\text { perasaan cemas disertai } \\
\text { detak jantung cepat dan } \\
\text { dapat menimbulkan agresi } \\
\text { ketika dijauhkan dari } \\
\text { gadget. }\end{array}$ & $\begin{array}{l}\text { Merasa harus selalu } \\
\text { menggunakan gadget } \\
\text { dimanapun dan } \\
\text { kapanpun }\end{array}$ & (Sundus, 2017) \\
\hline 3 & $\begin{array}{l}\text { Masalah } \\
\text { belajar }\end{array}$ & $\begin{array}{l}\text { Anak tidak lagi tertarik } \\
\text { untuk berinteraksi dengan } \\
\text { lingkungan belajar dan } \\
\text { hanya tertarik dengan } \\
\text { gadget sehingga } \\
\text { menghambat proses belajar. }\end{array}$ & $\begin{array}{l}\text { anak lebih banyak } \\
\text { menghabiskan waktunya } \\
\text { bermain gadget } \\
\text { dibandingkan untuk } \\
\text { belajar. }\end{array}$ & $\begin{array}{l}\text { (Utomo \& Budi, } \\
\text { 2015) }\end{array}$ \\
\hline 4 & $\begin{array}{l}\text { Dampak pada } \\
\text { karakter }\end{array}$ & $\begin{array}{l}\text { Pesatnya teknologi membuat } \\
\text { mudah membuka akses } \\
\text { apapun, dimana diketahui } \\
\text { banyak anak menggunakan } \\
\text { internet untuk melihat } \\
\text { konten dewasa daripada } \\
\text { mencari situs pendidikan. } \\
\text { Hal tersebut tentu } \\
\text { membawa dampak buruk } \\
\text { pada karakter anak karena } \\
\text { nilai moral akan terlupakan. }\end{array}$ & $\begin{array}{l}\text { Sarana menunjang akses } \\
\text { berselancar di internet }\end{array}$ & (Sundus, 2017) \\
\hline 5 & $\begin{array}{l}\text { Rendahnya } \\
\text { keterampilan } \\
\text { sosial }\end{array}$ & $\begin{array}{l}\text { Menurunnya intensitas } \\
\text { hubungan antar individu } \\
\text { dan mempengaruhi aktivitas } \\
\text { keseharian anak dengan } \\
\text { lingkungannya. }\end{array}$ & $\begin{array}{l}\text { fitur dan aplikasi dalam } \\
\text { gadget yang menarik, } \\
\text { membuat pengguna } \\
\text { gadget merasa asyik dan } \\
\text { sibuk dengan gadgetnya } \\
\text { sehingga membuat } \\
\text { mereka lupa dengan } \\
\text { orang-orang di sekitarnya }\end{array}$ & $\begin{array}{l}\text { (Frahasini et al., } \\
\text { 2018) } \\
\text { (Utomo \& Budi, } \\
\text { 2015) }\end{array}$ \\
\hline 6 & $\begin{array}{l}\text { Gangguan } \\
\text { kesehatan }\end{array}$ & $\begin{array}{l}\text { Radiasi dari gadget dapat } \\
\text { mengganggu kesehatan bagi } \\
\text { pengguna, seperti membuat } \\
\text { mata menjadi sakit, kering } \\
\text { dan berair sehingga } \\
\text { mengganggu aktivitas sehari } \\
\text { hari. }\end{array}$ & $\begin{array}{l}\text { Radiasi sinar dari gadget } \\
\text { Dampak negatif bagi } \\
\text { pecandu gadget adalah } \\
\text { munculnya gangguan } \\
\text { kesehatan. }\end{array}$ & $\begin{array}{l}\text { (Marpuah et al., } \\
\text { 2021) }\end{array}$ \\
\hline 7 & $\begin{array}{l}\text { Kualitas tidur } \\
\text { buruk }\end{array}$ & $\begin{array}{l}\text { Buruknya kualitas tidur } \\
\text { dapat berdampak pada } \\
\text { menurunkan daya } \\
\text { konsentrasi dikarenakan } \\
\text { mengantuk dan kelelahan } \\
\text { akibat kurang tidur. }\end{array}$ & $\begin{array}{l}\text { Lupa waktu karena } \\
\text { banyaknya fitur dan } \\
\text { aplikasi interaktif yang } \\
\text { membuatnya dapat } \\
\text { digunakan untuk melihat } \\
\text { konten foto, video dan } \\
\text { berinteraksi dengan orang } \\
\text { lain sepeti WhatsApp, } \\
\text { Twitter, Facebook, } \\
\text { Instagram, Youtube atau } \\
\text { Tik-tok. }\end{array}$ & $\begin{array}{l}\text { (Karki et al., 2021) } \\
\text { (Ivana et al., 2021) }\end{array}$ \\
\hline
\end{tabular}


Dengan bermain gadget anak juga tidak akan mendapatkan resiko terluka atau ancaman cidera seperti jika bermain di luar (Sundus, 2017). Hal tersebut menjadikan banyak orang tua memilih memberikan gadget kepada anaknya untuk mengurangi resiko anak bermain di luar tanpa pengawasan. Selain itu juga kesibukan orangtua dapat berpengaruh terhadap pengambilan keputusan untuk memberikan gadget kepada anak dengan alasan agar anak tidak rewel dan mengganggu aktifitas orangtua (Chusna, 2017). Akan tetapi dampak negatif dari penggunaan gadget bagi anak perlu untuk diperhatikan. M. Sundus (2017) menyebutkan beberapa dampak negatif terhadap penggunaan gadget seperti yang ditunjukkan pada tabel 2 .

\section{SIMPULAN}

Persoalan yang terjadi saat ini semakin memperburuk kualitas kecerdasan anak-anak karena adanya teknologi. Maka, pentingnya peran orang tua dalam mendidik anak di era digital ini perlu diperhatikan terutama pada aspek pola asuh yang transformatif. Artinya bahwa pengawasan dan pendampingan orang tua terhadap anak harus dilakukan secara berkala sehingga kontrol terhadap konten-konten negatif dunia digital bisa terhindarkan baik itu di rumah, sekolah, maupun lingkungan masyarakat dengan melibatkan stakeholder terkait. Kemudian, perlunya orang tua menggali ilmu pengethuan tentang psikologi juga penting untuk dilakukan supaya dampak-dampak (negatif) psikologi terhadap penggunaan perangkat digital secara berlebihan bisa diminimalisir. Mitigasi ini bertujuan untuk menjaga anak-anak agar memiliki kesehat mental yang baik dengan porsi pemanfaatan teknologi yang efektif.

\section{UCAPAN TERIMA KASIH}

Ucapan terimakasih penulis sampaikan kepada seluruh elemen yang telah membantu peneliti merampungkan artikel ini secara objektif. Penulis juga mengucapkan terima kasih kepada pengelola, reviewer, dan editor Jurnal Obsesi yang telah memberikan kesempatan kepada penulis, sekaligus membantu proses perbaikan artikel sehingga siap untuk diterbitkan.

\section{DAFTAR PUSTAKA}

Alia, T., \& Irwansyah. (2018). Pendampingan Orang Tua pada Anak Usia Dini dalam Penggunaan Teknologi Digital. A Journal of Language, Literature, Culture and Education, 14(1), 65-78. https:// doi.org/10.19166/pji.v14i1.639

Amalia Safitri, Y., Baedowi, S., \& Sari Setianingsih, E. (2020). Pola Asuh Orang Tua di Era Digital Berpengaruh Dalam Membentuk Karakter Kedisiplinan Belajar Siswa Kelas IV. MIMBAR PGSD Undiksha, 8(3), 508-514.

Andri, R. M. (2017). Peran dan Fungsi Teknologi Dalam Peningkatan Kualitas Pembelajaran. Jurnal Ilmiah Research Sains.

Andriyani, I. N. (2018). Pendidikan Anak dalam Keluarga di Era Digital. Fikrotuna, 7(1), 789802. https:// doi.org/10.32806/jf.v7i1.3184

Anisah. (2017). Pola Asuh Orang Tua Dan Implikasinya Terhadap Pembentukan Karakter Anak. Jurnal Pendidikan Universitas Garut, 5(1), 70-84.

APJII. (2020). Survei Pengguna Internet APJII 2019-Q2 2020: Ada Kenaikan 25,5 Juta Pengguna Internet Baru di RI. In Asosiasi Penyelenggara Jasa Internet Indonesia (Vol. 74, p. 1). https:/ / apjii.or.id/content/read/104/503/BULETIN-APJII-EDISI-74---November2020

Aromataris, E., \& Pearson, A. (2014). The Systematic Review : An Overview. AJN, 114(3), 5358. https:// doi.org/10.1097/01.NAJ.0000444496.24228.2c

Aslan, A. (2019). Peran Pola Asuh Orangtua di Era Digital. Jurnal Studia Insania, 7(1), 20. https://doi.org/10.18592/jsi.v7i1.2269 
Baharun, H., \& Finori, F. D. (2019). Smart Techno Parenting: Alternatif Pendidikan Anak Pada

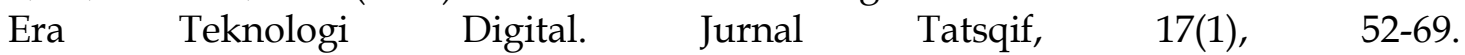
https:// doi.org/10.20414/jtq.v17i1.625

Bakti, A. F., \& Meidasari, V. E. (2014). Trendsetter Komunikasi di Era Digital: Tantangan dan Peluang Pendidikan Komunikasi dan Penyiaran Islam. Jurnal Komunikasi Islam, 04(01), 21-44.

Barni, M. (2019). Tantangan Pendidik Di Era Millennial. Jurnal Transformatif, 3(1), 99-116. https://doi.org/10.23971/tf.v3i1.1251

Chusna, P. A. (2017). Pengaruh Media Gadget Pada Perkembangan Karakter Anak. Dinamika Penelitian: Media Komunikasi Sosial Keagamaan.

Dunham, S. M., Dermer, S. B., \& Carlson, J. (2012). Poisonous parenting: Toxic relationships between parents and their adult children. In Poisonous Parenting: Toxic Relationships Between Parents and their Adult Children. https:/ / doi.org/10.4324/9780203852422

El Fiah, R., \& Hizri, M. (2020). Mendidik Anak dalam Keluarga Era Modern Perspektif Ibnu Ihsan Baihaqi. Jurnal Intelektualita: Keislaman, Sosial Dan Sains. https:// doi.org/10.19109/intelektualita.v9i1.5459

Frahasini, Astuti, T. M. P., \& Atmaja, H. T. (2018). The Impact of The Use of Gadgets in School of School Age Towards Children's Social Behavior in Semata Village Article Info. $\begin{array}{llll}\text { Journal of Educational Social Studies, } & \text { 7(2), }\end{array}$ https://journal.unnes.ac.id/sju/index.php/jess/article/view/26842

Hardiyanto, A. R. (2020). Problematika Proses Pembelajaran Pendidikan Agama Islam Berbasis Era Digital Di Man Kota Batu. Repository.Unisma.Ac.Id.

Hendayani, M. (2019). Problematika Pengembangan Karakter Peserta Didik di Era 4.0. Jurnal Penelitian Pendidikan Islam, 7(2), 183. https://doi.org/10.36667/jppi.v7i2.368

Ikawati, H. D. (2021). Pemanfaatan Tik Sebagai Strategi Mengatasi Tantangan Pendidikan Di Era Digital (Critical Review Artikel "Research-Informed Strategies to Address Educational Challenges in a Digitally Networked World"). Journal Scientific of Mandalika (JSM), 2(3), 95-100.

Ivana, I., Murniati, M., \& Ayu Trisno Putri, N. R. I. (2021). The Relationship Between Gadget Usage and Adolescent Sleep Quality. Journal of Public Health for Tropical and Coastal Region, 4(1), 23-27. https:// doi.org/10.14710/jphtcr.v4i1.10776

Karki, K., Singh, D. R., Maharjan, D., Sushmita, K. C., Shrestha, S., \& Thapa, D. K. (2021). Internet addiction and sleep quality among adolescents in a peri-urban setting in Nepal: A cross-sectional school-based survey. PLoS ONE, 16(2 February), 1-10. https:// doi.org/10.1371/journal.pone.0246940

Kerres, M., \& Bedenlier, S. (2020). Systematic Reviews in Educational Research. In Systematic Reviews in Educational Research. https:// doi.org/10.1007/978-3-658-27602-7

Khusni, M. F. (2018). Fase Perkembangan Anak Dan Pola Pembinaannya Dalam Perspektif Islam. Martabat: Jurnal Perempuan Dan Anak, 2(2). https:// doi.org/10.21274/martabat.2018.2.2.361-382

Lipsey, M. W., \& Wilson, D. B. (2001). Practical meta-analysis. In Applied Social Research Methods Series. SAGE Publications, Inc.

Marpuah, S., Zahari, W. A. M. W., Kirin, A., Mahmudah, U., \& Normawati, S. (2021). The Implications of Modern Technology (Gadjet) For Students Learning Development in University. Turkish Journal of Computer and Mathematics Education (TURCOMAT), 12(2), 588-593. https://doi.org/10.17762/turcomat.v12i2.912

Marryono Jamun, Y. (2018). Dampak Teknologi Terhadap Pendidikan. Jurnal Pendidikan Dan Kebudayaan Missio, 10(1), 48-52.

Nahriyah, S. (2017). Tumbuh kembang anak di era digital. Risalah, Jurnal Pendidikan Dan Studi Islam, 4(1), 65-74. https:// doi.org/10.14421/iga.2016.11-06

Nurulloh, E. S. (2019). Pendidikan Islam dan Pengembangan Kesadaran Lingkungan. Jurnal Penelitian Pendidikan Islam, 7(2). https:// doi.org/10.36667/jppi.v7i2.366 
DOI: 10.31004/obsesi.v6i3.1721

Putri, D. P. (2018). Pendidikan Karakter Pada Anak Sekolah Dasar Di Era Digital. ARRIAYAH : Jurnal Pendidikan Dasar, 2(1), 37. https://doi.org/10.29240/jpd.v2i1.439

Rahmat, S. T. (2018). Pola Asuh yang Efektif dalam Mendidik Anak di Era Digital. Journal $\begin{array}{llll}\text { Education and } & \text { Culture }\end{array}$ https://repasitory.stikipsantupaulus.ac.id/122/1/Artikel-jurnal-missio

Rahmawati, M., \& Latifah, M. (2020). Penggunaan Gawai, Interaksi Ibu-Anak, Dan Perkembangan Sosial-Emosional Anak Prasekolah. Jur. Ilm. Kel. \& Kons., 13(1), 75-86.

Ramdhani, M. A. (2014). Lingkungan Pendidikan dalam Implementasi Pendidikan Karakter. Jurnal Pendidikan Universitas Garut, 8(1), 28-37.

Rofiq, A., \& Nihayah, I. (2018). Komunikasi Sebagai Modal Utama Orang Tua Dalam Pembentukan Kepribadian Anak. OSF Preprints, 1-15. https://doi.org/10.31219/osf.io/2cxyt

Sobon, K., Mangundap, J. M., \& Walewangko, S. (2020). Pengaruh Penggunaan Smartphone Terhadap Motivasi Belajar Siswa Sekolah Dasar Di Kecamatan Mapanget Kota Manado. Autentik: Jurnal Pengembangan Pendidikan Dasar, 3(2), 97-106. https://doi.org/10.36379/autentik.v3i2.38

Soemartono, H. K. (2018). Survei APJII: Penetrasi Internet di Indonesia Capai 143 Juta Jiwa. In Buletin Asosiasi Penyelenggara Jasa Internet Indonesia: Vol. Edisi-22 2 (p. 3).

Sundus, M. (2017). The Impact of using Gadgets on Children. Journal of Depression and Anxiety, 07(01), 1-3. https://doi.org/10.4172/2167-1044.1000296

Syamsuar, \& Reflianto. (2019). Pendidikan Dan Tantangan Pembelajaran Berbasis Teknologi Informasi Di Era Revolusi Industri 4.0. Jurnal Ilmiah Teknologi Pendidikan, 6(2).

Tamara, R. M. (2016). Peranan Lingkungan Sosial Terhadap Pembentukan Kabupaten Cianjur. Jurnal Pendidikan Geografi, 44-55. https://doi.org/10.17509/gea.v16i1.3467

Trianingsih, R. (2016). Pengantar Praktik Mendidik Anak Usia Sekolah Dasar. Al Ibtida: Jurnal Pendidikan Guru MI, 3(2), 197. https:// doi.org/10.24235/al.ibtida.snj.v3i2.880

Trisnawati, W., \& Sugito, S. (2020). Pendidikan Anak dalam Keluarga Era Covid-19. Jurnal Obsesi: Jurnal Pendidikan Anak Usia Dini, 5(1), 823-831. https://doi.org/10.31004/obsesi.v5i1.710

Umami, I. U. F. (2019). Psikologi Remaja (Issue December). Idea Press. https://doi.org/10.5430/mos.v5n4p26

Utomo, C. B., \& Budi, T. (2015). Pengguna Gadget Di Sma N 1 Semarang. Journal of Educational Social Studies, 4(1), 1-5. http://journal.unnes.ac.id/sju/index.php/jess

Yuhana, A. N., \& Aminy, F. A. (2019). Optimalisasi Peran Guru Pendidikan Agama Islam Sebagai Konselor dalam Mengatasi Masalah Belajar Siswa. Jurnal Penelitian Pendidikan Islam, 7(1), 79. https://doi.org/10.36667/jppi.v7i1.357

Yuliawan, A. (2016). Hubungan Antara Motivasi Belajar Dan Latar Belakang Pendidikan Dengan Prestasi Belajar Mahasiswa. Profesi (Profesional Islam): Media Publikasi Penelitian, 14(1), 15. https:// doi.org/10.26576/profesi.132 